\title{
Bee Smoke Stick Dosage Form
}

National Cancer Institute

\section{Source}

National Cancer Institute. Bee Smoke Stick Dosage Form. NCI Thesaurus. Code

C149355.

Pharmaceutical impregnated sticks that deliver the active substance(s) when lit. This is used to treat bee hives and nests. 